\title{
Enhancing Motivation in the EFL Classrooms Is the Solution (A Case Study of Secondary Schools of the Gezira State, Sudan)
}

\author{
Abd ul-Gayoum M. A. al-Haj \\ Faculty of Education, the University of the Holy Qurán and Re-origination of Science, Madani, Sudan \\ Email: alhajabdo100@ hotmail.com
}

\begin{abstract}
The purpose of this paper is to explore and resolve the worse situation of motivation which is too often missing in Sudanese secondary students' classrooms and without it success in learning EFL is improbable. In order to solve this problem, the paper is conducted in some secondary schools of the Gezira State making use of three tools: the previous studies, the direct observations and the guided interviews in order to obtain valuable information. Then, the study comes out with the fact that, the bad situation of motivation in EFL Classrooms of secondary schools is due to many factors of which are: teachers and their training, schools, families and the lack of developing programmes which maintain students' interest. Then, the reasons for this worse situation of motivation in EFL Classrooms of secondary schools are discussed and the remedies are recommended as well.
\end{abstract}

Index Terms —enhancing motivation, EFL classrooms, solution

\section{INTRODUCTION}

The challenge of teaching is to enhance transfer and motivation so that they both support the learning of EFL. For transfer to take place the learner must be motivated to do two things. First, he must be able to recognize opportunities for transfer. Second, he needs to possess the motivation to take advantage of these opportunities. Hence, to motivate your students to learn is one of the good steps one can take to facilitate learning (Prewar, 1989 cited in Ngeow 1998, p.1). Bruner, (1960) argues that: "The best way to create interest in a subject is to render it worth knowledge, which means to make the knowledge gained usable in one's thinking beyond the situation in which learning has occurred"(p. $31)$.

The importance (significance) of this paper can be represented by the following advantages. First, it will be of value to community since a great number of EFL teachers might use its results and since it deals with a universal field of knowledge. Second, it may help in giving teachers a domestic ready-made subject, which concerning their career. Third, the researcher hopes that this paper will be an attempt by which he can help the specialized audience- such as: interested readers, teachers who are concerned with EFL, and those who are interested in language teaching and applied linguistics- to carry on researching in this area of knowledge.

\section{A. The Problem}

Teachers - of EFL - in secondary schools of the Gezira State do not:

1. offer learners the benefits that should be offered while teaching.

2. consider the idea of motivating the students.

3. make use of the underlying methodology and activities of the disciplines they deal with.

The researcher claims that teachers - of English - in secondary schools of the Gezira State do not motivate their students in EFL classes; this is on the one hand. On the other hand, these teachers are - to some extent - not qualified enough to use motivation while teaching, (Al-Haj, 2006, p.157). This claim has been strengthening with the fact that, teachers- of EFL- in secondary schools of the Gezira State do not use learning activities -like games, debates, etc.which motivate the students while they are learning English.

The above problem is a researchable one since it is possible for the researcher to gather data that answer the question: "Is it important for the EFL teacher to enhance motivation while teaching?" In other words, this problem can be attacked empirically. It is a problem that suits the researcher. First, he has a genuine interest in it. Second, it is a problem whose solution is personally important to him since it will contribute to his own knowledge as an educational practitioner. Third, it is in the area in which the researcher has both some knowledge and a reasonable experience (Al-Haj, 2006, p.5).

\section{B. Objectives of the Paper}

The following points can determine the objectives of this paper:

1. To state what is meant by motivation in doing things in general. 
2. To maximize the usefulness of motivation in teaching and learning EFL in secondary schools of the Gezira StateSudan.

3. To show that activities are important in making teaching and learning of EFL motivated in secondary schools of the Gezira State- Sudan.

4. To present the attributes of a good English language teacher of EFL who has to motivate his students while they are in the classroom.

5. To bridge some of the shortage of information on the part of the EFL teachers in secondary schools of the Gezira State- Sudan with regard to motivation.

\section{THE LiTERATURE REVIEW}

In this part of the paper, the researcher reviewed the relevant literature on the research problem. He has done this to gain more understanding and insight into the problem. Once he is satisfied that he has carried out a reasonably comprehensive search of the literature for his study, he proceeded to the task of organizing it. He arranged the study by topic and determined how each of these topics relates to the problem. As a matter of facts, the objectives of this study provide a framework for such arrangement. In other words, because the study investigates several objectives, the organization process is done separately for each one.

There is a widespread recognition that motivation is of great importance for successful foreign language acquisition, but there is less agreement about what motivation actually consists of. The term motivation has been used as "a general cover term- a dustbin- to include a number of possibly distinct concepts, each of which may have different origins and different effects and require different classroom treatment" (Mc Donough, 1981, p. 143).

Vincent, (1984) notes that the term 'motivation' is met frequently in psychological, educational and linguistic circles. At one level it refers to complex theories like: Hull's idea on drive reduction, Maslow's hierarchy of needs, and Mc Leland's emphasis on achievement. At another level, motivation covers such everyday concepts as what interests a person, what holds his attention, or most simply of all, what makes him act (p. 38)

Arno, (1981) defines motivation as any condition that initiates, guides, and maintains behaviour in an organism. For example, a young girl who is not hungry or thirsty may ignore a bottle of milk her parents set before her. Although she has learned to drink from the bottle, she will not engage in this behaviour if she is not motivated (p. 218)

Keller, (1983) provides the following simple definition: "Motivation refers to the choices people make as to what experience or goals they will approach or avoid, and the degree of effort they will exert in that respect."(p. 389). Yet, for a more thorough treatment of the definition, see Kleinginna and Kleinginna, (1981), who provide ninety-eight representative definitions grouped into nine categories (pp. 263-291).

\section{Methodology AND PROCEDURE}

\section{A. Methodology}

In the process of collecting and using the data (empirical investigation) the researcher measured the behaviour of students and teachers of secondary schools of the Gezira State while they were in classrooms. To achieve his goal, the researcher utilized three tools; namely:

1. Direct observations,

2. Guided interviews,

3. Relevant documents.

The researcher chooses these three tools as most appropriate for exchanging and evaluating ideas about motivation in the prescribed setting. Hamersley, (1996, cited in Al-Haj, 2006) claims that, "researchers can combine quantitative methods and qualitative ones in three ways: using one to verify the findings of the other, using one as the groundwork for the other, and using them both- in complementary fashion- to explore different aspects of the same research question" (p. 11).

\section{B. Procedure}

Then, the researcher outlined the procedure of developing the instruments, that is to say, he included the steps that taken to obtain validity and reliability of data on these instruments. Yet, the procedure which the researcher used was as follows: First, observations of teachers' class room behaviour are conducted, interviews are held for the collection of relevant data, and the relevant documents are dealt with. Second, the researcher discussed the findings and came out with conclusions and summary.

\section{CONCLUSIONS AND SUMMARY}

\section{A. Grounds for Lacking Motivation versus Remedies}

The researcher makes observations, thinks about the problem, turns to the literature for clues, makes additional observations, and then finds that the students of secondary schools of the Gezira State are not motivated when they learn EFL. He claims that the main reason of this shortcoming is that, teaching in some secondary schools of the Gezira 
State is not effective; however, an effective teaching is an essential factor in learning EFL efficiently.

As a matter of fact, the use of an interesting text can help to increase the motivation level of students while they are in their EFL classrooms. But, in secondary schools of the Gezira State, EFL texts contain materials which fail to capture the interest of students due to the heavy emphasis on vocabulary. In addition to that, many EFL teachers have poor listening and speaking skills, thus relying on vocabulary and grammatical understanding of the English language.

\section{B. Findings}

Considering the above results of the quantitative and qualitative data, the researcher claims that the following findings support the fact of lacking motivation, since most of the EFL teachers of secondary schools of the Gezira State do not:

1. have interest in what they are teaching.

2. vary their teaching activities.

3. encourage their students while they are teaching.

4. respond to their students' needs.

5. teach passages that interest their students.

The researcher claims that a variety of classroom activities play an essential part in motivating students and facilitating the acquisition of EFL. These activities can reduce the strain of formality in the classroom and make learning more student-centred and less teacher-centred. In addition to that, activities carried out in groups may help to motivate and encourage the more diffident students and those who are evasive, or afraid to ask or speak for fear of making errors, that is because activities carried out in groups will transfer the process of learning from getting the skill of the language to using it. (Najat and Taiseer, 1998, p.157)

The researcher agrees with Hutchinson, and Waters, (1987) claim, that "EFL, as much as any good teaching, needs to be intrinsically motivating. It may, still, need to be sweetened with the sugar of enjoyment, fun, creativity, and a sense of achievement." Bearing the above result in his mind, the researcher finds them as supported the fact, that: (There are many activities by which teachers - of English - in secondary schools of the Gezira State can make learning of the target language interesting in classes of EFL). This fact has been strengthening with the claim that, the EFL teachers of secondary schools of the Gezira State do not:

1. use learning activities like games, debates, etc., while they are teaching.

2. arrange the class in pairs (i.e., in twos).

3. make use of drama-like classroom activities, while they are teaching.

4. use games as activities that set up competition between students.

5. use pictures, tapes, stories, etc. in order to make their teaching interesting.

6. call the students by their names, etc.

As the researcher noted earlier, the type of teaching EFL in secondary schools of the Gezira State does not utilize the characteristics of teaching for effective learning, as Effective teaching goes beyond knowing about subject or topic. Considering the above-mentioned basic principles of Hutchinson and Waters, (1987, p.72) about the learning-centred methodology, the researcher gives an essential remark that all these findings supported the fact that: "There are many characteristics of both effective teaching and effective learning of EFL which are not adopted by EFL teachers of secondary schools of the Gezira State." Hence, the researcher claims that some findings of the quantitative and qualitative data (concerning the learning-centred methodology) are as follows:

1. Student behaviour is not monitored.

2. Class routines and teaching procedures are not handled efficiently.

3. There is no matching between grouping arrangements and instructional needs.

4. When students do not learn, they are not re-taught.

5. Teacher-student interactions are, to some extent, not positive, etc.

The researcher stated that, the results of the interviews together with the observational comments reflected an important part of the paper's problem that, "There are many qualities, of a good teacher of EFL, which are unheeded by the teachers who teach English as a Foreign Language in secondary schools of the Gezira State". For instance, most of the EFL teachers in these schools do not:

1. create among their students a feeling of security and confidence.

2. satisfy their students' needs.

3. praise their students when they do well.

4. have to depend entirely on the textbooks.

5. have a passion for teaching.

Bearing the interviews' and the observations' outcomes in his mind the researcher stated that, the EFL teachers of secondary schools of the Gezira State need to be able to understand two important aspects. First, they have to understand the discourse of the classroom, that is to say, to master the language of teaching as well as the discourse of the texts that students use. Second, they have to "plan the course they teach and provide the materials for it. These teachers, also, need to assess the effectiveness of the teaching material used, whether that material is published or self-produced." (Dudley-Evans and St. John, 1998, p.14).

It is evident that, the EFL teachers of secondary schools of the Gezira State need to have a sufficient knowledge 
between them and their students, specially, in the field of teaching. Richards, et al. (1992, p.179) declare that, in order to promote real communication between students, there must be an information gap between them, and between them and their teacher. According to Dudley-Evans and St. John (1998), to have this information gap, each EFL teacher must consider himself a practitioner who has the following "five key roles: teacher, course designer, materials provider, collaborator, researcher, and evaluator." (p.13).

\section{RECOMMENDATIONS}

Most of the teachers - of English - in secondary schools of the Gezira State are not qualified enough to use motivation while teaching. To remedy this problem the researcher claims that: (There are many activities by which these teachers can make learning of the target language motivated in classes of EFL.) Therefore, he presents the recommendations below as a framework by which English Language teachers can deal with such a problem.

\section{A. Stimulating and Motivating the Students.}

Some students are evasive, or afraid to ask or to speak for fear of making errors. The teacher's duty is to encourage such students to talk in English and to praise their performance and progress, no matter how limited it may be. This encouraging attitude will create a pleasant atmosphere, motivate the pupils and make English classes lively and enjoyable. In addition to that, nothing is more disappointing for a student than to feel ignored, neglected, or carelessly evaluated, or to feel that his work does not appeal to the teacher. An encouraging attitude in the part of the teacher motivates students and makes them interested in learning the language. In this respect, the researcher recommends the following points for EFL teachers who want to stimulate or motivate their students:

1. Be interested in what you are teaching.

2. Make your lesson interesting with pictures, stories, etc.

3. Vary your learning activities, by using:

- debates.

- games.

- group and pair work.

- presenting play lets.

- mock interviews.

- problem-solving.

- role-playing, etc.

4. Vary your teaching method as well as your voice.

5. Make a good introduction to your lesson.

6. Make sure that your work is well graded.

7. Respond to your students' needs.

8. Give your students opportunities, to participate by:

- asking them questions.

- involving them in group or pair work.

- giving them written or practical exercises.

9. Do not guide and control your students too much.

10. Create among your students a feeling of security and confidence.

11. Give easier questions to weaker students and tougher questions to brighter ones.

12. Reward good work.

13. Mark and return your students' work promptly.

14. Have all the apparatus ready when doing practical.

The researcher claims that no single style or approach to classroom organization is best. He, also, indicates that a variety of classroom activities play an essential part in motivating students and facilitating the acquisition of EFL. He, also, claims that these activities can reduce the strain of formality in the classroom and make learning more student-centred and less teacher-centred. Activities carried out in groups may help to motivate and encourage the more diffident students. Activities transfer the process of learning from getting the skill of the language to using it. Bearing the above results in his mind, the researcher claims that these findings supported the fact, that: (There are many activities by which teachers - of English - in secondary schools of the Gezira State can make learning of the target language effective in classes of EFL).

\section{B. Making Use of Group \& Pair Work}

In order to increase students' participation, the teacher must employ techniques that require the students to utilize the language creatively as an instrument of learning. In this regard, he can provide them with effective communication skills and with an understanding of the foreign language culture. An experienced teacher plans the work in a way that keeps the students on their toes. The EFL teacher must thus provide the class with a wide range of learning activities -for the group and the individual -which can hold the student's attention, and stimulate them to interact and communicate in the language. Such a variety of activities will also prevent boredom and cater for the range of interests 
of the individuals in the class.

Long and Porter, (1985, cited in Rod 1996, p.598) make a summary that the main pedagogical arguments are in favour of group work. They say that, it increases language practice opportunities, it improves the quality of student talk, it helps to individualize instruction, and it promotes a positive affective climate, and motivates learners to learn. Agreeing with the above arguments the researcher recommends the following points for EFL teachers - of secondary schools of the Gezira State - who want to make use of group / pair work and other learning activities, while they are teaching. Therefore, these teachers have to:

1. provide the class with learning activities like games, debates, etc.

2. group the class in pairs (i.e., in twos), while they are teaching.

3. use role-playing (i.e., drama-like classroom activity), while they are teaching.

4. use problem-solving activities that suit their student's interest.

5. make use of games as activities that set up competition among their students.

6. make their teaching interesting by making use of pictures, tapes stories, etc.

7. use learning activities - in the classroom - that match their students level.

8. make changes to the classroom activities, while they are teaching.

9. use learning activities that related to their students' culture.

\section{Deploying the Principles of Effective Teaching}

In order to solve these problems and to make use of the learning-centred methodology the researcher recommends the following points for EFL teachers who want to deploy the principles of effective teaching for effective learning:

1. Try to establish and exploit what the learners already know, as EFL learning is a developmental process.

2. Use group work to build on existing social relationship, as group work increases language practice opportunities, improves the quality of student talk, helps to individualize instruction, promotes a positive affective climate, and motivates learners to learn.

3. Work hard to incorporate greater use of oral English within the classrooms.

4. You have to know that, English as a Foreign Language can be learnt incidentally, while you are actually thinking about something else.

5. After having the necessary knowledge, to make things meaningful students must use that knowledge.

6. A sound approach to EFL must rely on knowing the 'processes of language learning'.

7. In EFL classes, emphasis should be on pair or group work and problem solving, which allow for the students' differences.

As a matter of fact, all the above findings supported the idea that, "There are many qualities, of a good teacher of EFL, which are not heeded by the teachers who teach English in secondary schools of the Gezira State-Sudan" According to Dudley-Evans and St. John, (1998) EFL teaching is extremely varied, and for this reason they use the term 'practitioner' rather than 'teacher' to emphasize that EFL work involves much more than teaching. (p.13).

\section{CONCLUSION}

Teachers - of English - in secondary schools of the Gezira State do not motivate their students in EFL classes, this is on the one hand. On the other hand, these teachers are - to some extent - not qualified enough to use motivation while teaching, (Al-Haj, 2006, p.157). This claim has been strengthening with the fact that, these teachers do not use learning activities-like games, debates, etc.-which motivated the students while they are learning English as a target language. Therefore, in order to make the process of learning EFL in secondary schools of the Gezira State a more motivating and effective experience, the researcher hopes that the above-mentioned recommendations and suggestions should be implemented.

If that has been done, the researcher will expect the following benefits. The research will be of value to community since it deals with a universal field of knowledge. It might help in giving EFL teachers of secondary schools of the Gezira State a domestic ready-made subject concerning their career. Then, the researcher hopes that this research paper will be an attempt by which he can help those who want to write researches in this area of study.

\section{ACKNOWLEDGMENTS}

I would like to extend my gratitude to my uncle Ustaz Abd el-Hafeez Salih Ali for being a real help to me. My gratitude is, also, conveyed to Ustaz Abd el-Rahman Omer of University of the Holy Qurān for his helpful comments and to all my colleagues -the English language teachers- who examined this paper.

I am, also, indebted to my friends and colleagues who served with me the University of the Holy Qurān, the organization from which I have learned the most about devoting oneself for the benefits of others.

Lastly, praise is to Allah (Almighty) who guides all our deeds and actions for surely I would not have achieved anything without His Guidance. I would like to say that, any absurdities which remain are, of course, my own. 
[1] Al-Haj, A. M. (2003). Motivation as a Contributing Factor in Learning EFL. Gezira University, MA: Hasahiesa.

[2] Al-Haj, A.M. (2006). Effective Teaching for Effective Learning of ESP in the University of the Holy Qurān. Wadi el-Neel University, PhD: Omderman.

[3] Arno, F. W. (1981). Theory and Problems of Psychology of Learning. McGraw-Hill Book Company. pp:218-23

[4] Bruner, J. S. (1960). The Process of Education. Cambridge, MA: Harvard. [EJ047959]. P: 31

[5] Dudley-Evans, A. and M. J. St John. (1998). Developments in English for Specific Purposes. Cambridge Language Teaching Library. Cambridge University Press.

[6] Hornby, A. S. (2000). Oxford Advanced Learner's Dictionary. Oxford University press. Oxford. New York.

[7] Hutchinson, T. and A. Waters. (1987). English for Specific Purposes. Cambridge: Cambridge University press.

[8] Keller, J. M. (1983). Motivational Design of Instruction. In C. M. Reigeluth (Ed.), Instructional Design Theories and Models. Hillsdale, New Jersey: Erlbaum, pp:386-433

[9] Kleinginna, P. R. and Kleinginna, A. M. (1981). A Categorized List of Motivational Definitions, with a Suggestion for a Consensual Definition. Motivation and Emotion, 5, pp:263-291

[10] Laurence, U. and Martin, M. (1978).The Pan Dictionary of Synonyms and Antonyms. Pan Reference. London and Sydney.

[11] McDonough, S. H. (1981). Psychology in Second Language Teaching. Allen and Unwin, London. P:143

[12] Najat, A. and Taiseer, K. (1998). Methods of Teaching English to Arab Students. Longman Handbooks: Longman pp:8,156 - 58

[13] Ngeow, K. (1998). Motivation and Transfer in Language Learning. ERIC Digest. ERIC Clearing House. pp: $1-5$

[14] Richards, J. G., John, P. and Heidi, P. (1992). Dictionary of Language Teaching and Applied Linguistics. Longman.

[15] Rod, E. (1996). The Study of Second Language Acquisition. Oxford University Press. pp: 508-17.

[16] Vincent, M. (1984). Motivation and its Importance in ELT. pp: 37 - 43.In: Holden, S.,(ed.). Focus on the Learner. Modern English Publications.

Abd ul-Gayoum M. A. al-Haj was born in Wadmadani central Sudan in 1955. He has: - Ph.D. in English Language (Applied Linguistics) from Nile Valley University- Omdurman- Sudan(2006). - M.A. in Applied Linguistics, Gezira University- WadmadaniSudan (2003). - B.A. in Education (English), Faculty of Education- University of Khartoum- Khartoum- Sudan (1985). Major field is Applied Linguistics \& ELT.

Dr. Al-Haj has the following experiences: - School of Languages Dean. Karary University- Khartoum Province- Sudan (Nov. 2009-Now). - Dean of the Faculty of Education. The Holy Qurān University- Wad Madani- Gezira Province- Sudan (June. 2007Nov. 2009 ). - Dean of the Faculty of Community Development. The HQU - Juba Branch- Juba- Sudan (Nov. 2005-May - 2007). Now, Dr. Al-Haj is the Dean of the School of Languages- Karary University- Khartoum- Sudan. His current and previous research interests are to write research papers in Applied Linguistics and ELT. Previous publications:(Two Books): - Phonetics Made EasyKhartoum -Al-Barakat Printing Press- 2006. -Techniques of Teaching EFL- Khartoum -Al-Barakat Printing Press- 2007.

Dr. Al-Haj is a member of: - the Human Research Ethics Committee of the National Institute of Cancer \& Gezira UniversitySudan. - British Council Board for English as a Foreign Language Teachers. - (ASTEL) Association of Sudanese Teachers of English Language. He has been awarded the HQU Prize for his research paper-about developing Juba Branch- which was classified as the best study out of (66) research papers. 